\title{
Evidence that adverse effects of zinc deficiency on essential fatty acid composition in rats are independent of food intake
}

\author{
BY STEPHEN C. CUNNANE \\ Department of Nutritional Sciences, University of Toronto, Toronto, Canada MSS 1A8
}

(Received 4 September 1987 - Accepted 9 November 1987)

1. Young male rats were fed on diets containing $3 \cdot 4,36$ or $411 \mathrm{mg}$ zinc/ $\mathrm{kg}$ for 10 weeks in order to determine whether effects of $\mathrm{Zn}$ deficiency on plasma and liver essential fatty acid composition could be distinguished from those of reduced protein and energy intake.

2. Fatty acid analysis revealed that a $\mathrm{Zn}$ intake of $3.4 \mathrm{mg} / \mathrm{kg}$ (plasma $\mathrm{Zn} 0.80$ v. $1.97 \mathrm{mmol} / \mathrm{l}$ in controls fed on $36 \mathrm{mg} \mathrm{Zn} / \mathrm{kg}$ ) resulted in a significant increase in the linoleic acid : arachidonic acid ratio in both plasma and liver phospholipids in comparison with rats fed on 36 or $411 \mathrm{mg} \mathrm{Zn} / \mathrm{kg}$.

3. $\mathrm{Zn}$ supplementation $(411 \mathrm{mg} / \mathrm{kg})$ decreased the linoleic acid:arachidonic acid ratio in plasma phosphatidylserine compared with that of the controls.

4. The previously reported increase in arachidonic acid ( $\mathrm{mol} \%$ ) in liver triacylglycerol of $\mathrm{Zn}$-deficient rats was shown to be a function of a reduced liver triacylglycerol pool size; quantitatively, triacylglycerol content of arachidonic acid in the liver was not significantly affected by $\mathrm{Zn}$ intake.

The interaction between zinc and essential fatty acid (EFA) metabolism has been the subject of considerable research. Initially, studies involving supplementation of $\mathrm{Zn}$-deficient humans or rats with EFA added to the diet, or the exacerbation of EFA deficiency by $\mathrm{Zn}$ deficiency, suggested a role of $\mathrm{Zn}$ in EFA metabolism (Cunnane, 1982). Fatty acid values from total lipid extracts of tissues indirectly confirmed earlier work (Bieri \& Prival, 1966; Bettger et al. 1979; Odutunga, 1982; Huang et al. 1982; Krieger et al. 1986). More recently, studies of the interaction of $\mathrm{Zn}$ in EFA metabolism have focused on the $\Delta 6-$ and $\Delta 5-$ desaturases which control synthesis of arachidonic acid $(20: 4 n-6)$. Reports describing in vitro assay of desaturase activity in both ad lib.-fed and pair-fed controls have demonstrated impaired synthesis of arachidonic acid in Zn-deficient rats (Clejan et al. 1982; Ayala \& Brenner, 1983; Fields \& Kelleher, 1983; Tsai et al. 1983).

In spite of this evidence, the experimental conditions used have left unresolved the effects of altered appetite and food intake induced by feeding a diet depleted of $\mathrm{Zn}$. The inhibitory effect of $\mathrm{Zn}$ deficiency on food intake is maximal in the young rat 2-3 weeks post-weaning. If rats at this age are fed on a diet with no added $\mathrm{Zn}$ (final $\mathrm{Zn}$ concentration $0.5-1.0 \mathrm{mg}$ $\mathrm{Zn} / \mathrm{kg}$ diet), pair-feeding indicates that reduced food intake has a significant effect on EFA composition and metabolism regardless of $\mathrm{Zn}$ intake (Kramer et al. 1984). However, if the

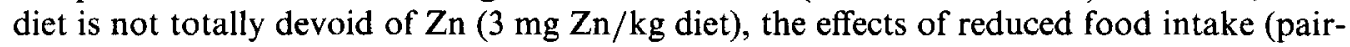
feeding) and $\mathrm{Zn}$ deficiency are clearly distinguishable (Cunnane et al. 1984).

The recent report of Fogerty et al. (1985) has added to the debate by demonstrating that in adult rats, arachidonic acid (mol \%) was increased in the extract of the total or neutral lipids of liver. Their report supports previous observations (Huang et al. 1982; Cunnane et al. 1984) suggesting that the effect of $\mathrm{Zn}$ deficiency on the proportional content of arachidonic acid in liver lipids depends on whether phospholipids or neutral lipids are being assayed. The present study seeks to address these issues and to investigate whether (a) $\mathrm{Zn}$ deficiency affects EFA composition independently of food intake, (b) Zn supplementation has effects consistent with a role of $\mathrm{Zn}$ in EFA metabolism, (c) it is important to distinguish 
between phospholipids and neutral lipids in relating effects on fatty acid composition to nutrient imbalances. These points require clarification if a significant role of $\mathrm{Zn}$ in EFA metabolism is to be established.

\section{METHODS}

Thirty weanling male Sprague-Drawley rats (mean weight 50 (SE 2) g) were housed individually in polypropylene cages with stainless-steel gridded wire floors and cage tops (Nalgene). They were fed on a semi-synthetic diet (Teklad, Madison, Wl) in which the Zn content was formulated to be $40 \mathrm{mg} / \mathrm{kg}$. The diet contained $(\mathrm{g} / \mathrm{kg}): 200$ spray-dried egg white, 505 maize starch, 100 maize oil, 150 cellulose, 35 AIN-76 mineral mix and 10 AIN$76 \mathrm{~A}$ vitamin mix as recommended by the American Institute of Nutrition (1977). At $10 \mathrm{~d}$ post-weaning (mean body-weight 95 (SE 4) g), the rats were divided into three groups of ten rats each and were given the same diet in which the $\mathrm{Zn}$ content was formulated to be $4 \mathrm{mg} /$ $\mathrm{kg}(\mathrm{Zn}(-)), 40 \mathrm{mg} / \mathrm{kg}$ (control) or $400 \mathrm{mg} / \mathrm{kg}(\mathrm{Zn}(+))$. The measured $\mathrm{Zn}$ content of these diets was $3 \cdot 4,36$ and $411 \mathrm{mg} / \mathrm{kg}$ respectively. Deionized, distilled water was available $a d$ lib. from acid-washed polycarbonate bottles with stainless-steel sippers (Nalgene). The rats were weighed weekly and food intake was measured daily. After 10 weeks on the diets, the rats were anaesthetized under diethyl ether and blood was drawn from the abdominal aorta into EDTA-anticoagulated syringes, centrifuged and the plasma frozen. Liver was also removed and frozen.

Lipid analysis was conducted as described previously (Cunnane et al. 1984). Total lipids of plasma and liver were extracted with chloroform-methanol $(2: 1, \mathrm{v} / \mathrm{v})$ containing $0.2 \mathrm{~g}$ butylated hydroxytoluene/l as antioxidant. Total phospholipids and triacylglycerols (liver only) were separated by thin-layer chromatography using standard methods (Cunnane et al. 1984). These lipid fractions were trans-esterified with boron trifluoride-methanol and the composition of the fatty acid methyl esters was determined by gas-liquid chromatography under the conditions previously specified (Cunnane et al. 1984). Total phospholipids were quantified by the ammonium ferrothiocyanate method (Stewart, 1980) and triacylglycerols were quantified by gas-liquid chromatography using triheptadecanoin as the internal standard. The $\mathrm{Zn}$ content of the diet and plasma was assayed by atomic absorption spectrophotometry (Instrumentation Laboratories 457) under conditions of minimal contamination.

Statistical analyses were done using one-way analysis of variance followed by Duncan's Multiple Range Test.

\section{RESULTS}

The weight gained by the $\mathrm{Zn}(-)$ rats was $43 \%$ lower than that gained by either the controls or the $\mathrm{Zn}(+)$ group $(P<0.01)$. Absolute food intake was not different between groups but food conversion efficiency ( $\mathrm{g}$ weight gain $/ \mathrm{g}$ food intake) was only $65 \%$ of control values in the $\mathrm{Zn}(-)$ group $(P<0.01$, Table 1$)$. Liver weight (absolute and relative to body-weight) was significantly lower in the $\mathrm{Zn}(-)$ group compared with either the controls or $\mathrm{Zn}(+)$ group. Plasma $\mathrm{Zn}$ level in the $\mathrm{Zn}(-)$ group was $40 \%$ of that in the controls $(P<0.01)$ and was $34 \%$ higher than control values in the $\mathrm{Zn}(+)$ group (not significant).

The main fatty acids relevant to the role of $\mathrm{Zn}$ in EFA metabolism are linoleic acid $(18: 2 n-6)$, dihomo- $\gamma$-linolenic acid $(20: 3 n-6)$ and arachidonic acid $(20: 4 n-6)$ in the phospholipid fractions. The values describing phospholipid fatty acid composition are therefore limited to these fatty acids (Table 2 and 3). In liver, triglyceride levels of the nonEFA, palmitic acid $(16: 0)$, palmitoleic acid $(16: 1 n-7)$ and oleic acid $(18: 1 n-9)$, are also shown (Table 3). 
Table 1. Effects of altered zinc intake on body-weight, food intake, liver weight and plasma $\mathrm{Zn}$ concentrations of rats

(The $\mathrm{Zn}(-$ ) diet contained $3.4 \mathrm{mg} \mathrm{Zn} / \mathrm{kg}$, the control diet $36 \mathrm{mg} \mathrm{Zn} / \mathrm{kg}$ and the $\mathrm{Zn}(+)$ diet $411 \mathrm{mg}$ $\mathrm{Zn} / \mathrm{kg}$. Values are means with their standard errors for ten rats/group)

\begin{tabular}{|c|c|c|c|c|c|c|}
\hline \multirow[t]{2}{*}{ Group... } & \multicolumn{2}{|c|}{$\mathrm{Zn}(-)$} & \multicolumn{2}{|c|}{ Control } & \multicolumn{2}{|c|}{$\mathrm{Zn}(+)$} \\
\hline & Mean & SEM & Mean & SEM & Mean & SEM \\
\hline Final body-wt (g) & $281^{a}$ & 11 & $425^{b}$ & 17 & $451^{\mathrm{b}}$ & 9 \\
\hline Change in body-wt (g) & $193^{a}$ & 10 & $339^{b}$ & 7 & $350^{\mathrm{b}}$ & 20 \\
\hline Food intake $(\mathrm{g} / \mathrm{d})$ & $10 \cdot 2$ & $2 \cdot 0$ & $12 \cdot 4$ & 1.6 & 9.9 & $1 \cdot 7$ \\
\hline $\begin{array}{l}\text { Body-wt gain/food } \\
\text { intake }(\mathrm{g} / \mathrm{g})\end{array}$ & $0 \cdot 26^{a}$ & 0.04 & $0.40^{\mathrm{b}}$ & 0.05 & $0.51^{\mathrm{b}}$ & 0.05 \\
\hline Liver wt $(\mathrm{g})$ & $8 \cdot 2^{\mathrm{a}}$ & 0.5 & $15 \cdot 4^{\mathrm{b}}$ & 0.7 & $13 \cdot 7^{\mathrm{b}}$ & $1 \cdot 0$ \\
\hline Liver: body-wt $(\mathrm{g} / \mathrm{kg})$ & $29^{a}$ & 0.2 & $36^{\circ}$ & $0 \cdot 2$ & $30^{\mathrm{b}}$ & $0 \cdot 3$ \\
\hline Plasma $\mathrm{Zn}(\mathrm{mmol} / \mathrm{l})$ & $0.80^{\mathrm{a}}$ & $0 \cdot 20$ & $1.97^{\mathrm{b}}$ & 0.26 & $2 \cdot 65^{\mathrm{b}}$ & 0.29 \\
\hline
\end{tabular}

$a_{,}$balues in horizontal rows with different superscript letters were significantly different (one-way ANOVA and Duncan's Multiple Range Test): $P<0.01$.

Table 2. Effect of altered zinc intake on the fatty acid composition (mol\%) of two plasma phospholipid subclasses and plasma concentration of phosphatidylcholine and phosphatidylserine

(The $\mathrm{Zn(-)}$ diet contained $3.4 \mathrm{mg} \mathrm{Zn} / \mathrm{kg}$, the control diet $36 \mathrm{mg} \mathrm{Zn} / \mathrm{kg}$ and the $\mathrm{Zn}(+)$ diet $411 \mathrm{mg}$ $\mathrm{Zn} / \mathrm{kg}$. Values are means with their standard errors for ten rats/group)

\begin{tabular}{|c|c|c|c|c|c|c|}
\hline \multirow[t]{2}{*}{ Group... } & \multicolumn{2}{|c|}{$\operatorname{Zn}(-)$} & \multicolumn{2}{|c|}{ Control } & \multicolumn{2}{|c|}{$\operatorname{Zn}(+)$} \\
\hline & Mean & SEM & Mean & SEM & Mean & SEM \\
\hline \multicolumn{7}{|l|}{ Phosphatidylcholine } \\
\hline $18: 2 n-6$ & $31 \cdot 1^{\mathrm{a}}$ & 1.7 & $23 \cdot 4^{b}$ & $2 \cdot 5$ & $22 \cdot 1^{\mathrm{b}}$ & 1.9 \\
\hline $20: 3 n-6$ & $0 \cdot 7^{a}$ & $0 \cdot 1$ & $1 \cdot 3^{\mathrm{b}}$ & 0.2 & $0 \cdot 5^{\mathrm{a}}$ & $0 \cdot 1$ \\
\hline $20: 4 n-6$ & $20 \cdot 1^{\mathrm{a}}$ & $2 \cdot 0$ & $25 \cdot 7^{\mathrm{a}}$ & $2 \cdot 3$ & $30 \cdot 4^{b}$ & 1.9 \\
\hline $18: 2 n-6 / 20: 4 n-6$ & $1.55^{\mathrm{a}}$ & 0.20 & $0.94^{\mathrm{b}}$ & 0.12 & $0.72^{b}$ & 0.06 \\
\hline $\mathrm{mmol} / 1$ & $7 \cdot 3$ & 1.7 & $9 \cdot 1$ & $1 \cdot 3$ & $8 \cdot 4$ & $1 \cdot 5$ \\
\hline \multicolumn{7}{|l|}{ Phosphatidylserine } \\
\hline $18: 2 n-6$ & $20 \cdot 6$ & $2 \cdot 0$ & $21 \cdot 0$ & $1 \cdot 3$ & $17 \cdot 5$ & $1 \cdot 1$ \\
\hline $20: 3 n-6$ & $0 \cdot 4^{\mathrm{a}}$ & 0.05 & $1 \cdot 1^{\mathrm{D}}$ & $0 \cdot 1$ & $0 \cdot 3^{\mathrm{a}}$ & 0.04 \\
\hline $20: 4 n-6$ & $14 \cdot 1^{\mathrm{a}}$ & 0.8 & $17 \cdot 5^{\mathrm{a}}$ & $0 \cdot 6$ & $19 \cdot 7^{\mathrm{b}}$ & $0 \cdot 3$ \\
\hline $18: 2 n-6 / 20: 4 n-6$ & $1 \cdot 44^{\mathrm{a}}$ & 0.11 & $1 \cdot 21^{\mathrm{a}}$ & 0.90 & $0.90^{\mathrm{b}}$ & $0 \cdot 06$ \\
\hline $\mathrm{mmol} / \mathrm{l}$ & 4.0 & 0.4 & $5 \cdot 8$ & $1 \cdot 2$ & 5.0 & 0.7 \\
\hline
\end{tabular}

${ }^{a, b}$ Values in horizontal rows with different superscript letters were significantly different (one-way ANOVA and Duncan's Multiple Range Test) $: P<0-01$.

The fatty acid composition of the two main phospholipid subclasses of plasma is shown in Table 2. The proportional content of linoleic acid was significantly higher in the phosphatidylcholine subclass of the $\mathrm{Zn}(-)$ group than in the other groups but did not differ significantly between groups in the phosphatidylserine fraction. In each of the plasma phospholipid subclasses studied, dihomo- $\gamma$-linolenic acid was significantly higher in the controls than in the other groups whereas arachidonic acid was lowest in the $\mathrm{Zn}(-)$ group (not significant compared with controls) and highest in the $\mathrm{Zn}(+)$ group $(P<0.01$, Table 
Table 3. Phospholipid and triacylglycerol fatty acid composition (mol\%) and total phospholipid and triacylglycerol content of liver in rats fed on different amounts of dietary zinc

(The $\mathrm{Zn}(-)$ diet contained $3.4 \mathrm{mg} \mathrm{Zn} / \mathrm{kg}$, the control diet $36 \mathrm{mg} \mathrm{Zn} / \mathrm{kg}$ and the $\mathrm{Zn}(+)$ diet $411 \mathrm{mg}$ $\mathrm{Zn} / \mathrm{kg}$. Values are means with their standard errors for ten rats/group)

\begin{tabular}{|c|c|c|c|c|c|c|}
\hline \multirow[t]{2}{*}{ Group... } & \multicolumn{2}{|c|}{$\mathrm{Zn}(-)$} & \multicolumn{2}{|c|}{ Control } & \multicolumn{2}{|c|}{$\mathrm{Zn}(+)$} \\
\hline & Mean & SEM & Mean & SEM & Mean & SEM \\
\hline \multicolumn{7}{|l|}{ Phospholipid: } \\
\hline $18: 2 n-6$ & $17 \cdot 1^{\mathrm{a}}$ & 0.6 & $13 \cdot 8^{\mathrm{b}}$ & 0.5 & $12 \cdot 2^{\mathrm{b}}$ & 0.7 \\
\hline $20: 3 n-6$ & $0 \cdot 9^{\mathrm{a}}$ & $0 \cdot 1$ & $0 \cdot 7^{\mathrm{a}}$ & 0.1 & $1 \cdot 6^{\mathrm{b}}$ & 0.2 \\
\hline $20: 4 n-6$ & $31 \cdot 7$ & $0 \cdot 2$ & $32 \cdot 9$ & $0 \cdot 6$ & $31 \cdot 0$ & 0.8 \\
\hline $18: 2 n-6 / 20: 4 n-6$ & $0.54^{\mathrm{a}}$ & 0.02 & $0 \cdot 42^{b}$ & 0.02 & $0.39^{\mathrm{h}}$ & 0.03 \\
\hline $\mathrm{mg} / \mathrm{g}$ & $19 \cdot 1$ & 0.8 & 17.6 & $0 \cdot 3$ & $16 \cdot 7$ & 0.5 \\
\hline \multicolumn{7}{|l|}{ Triacylglycerol: } \\
\hline $16: 0$ & $18 \cdot 2^{\mathrm{a}}$ & $2 \cdot 6$ & $30 \cdot 0^{\mathrm{b}}$ & $1 \cdot 3$ & $24 \cdot 7^{\mathrm{c}}$ & $1 \cdot 4$ \\
\hline $16: \ln -7$ & $2 \cdot 3^{\mathrm{a}}$ & 0.4 & $3 \cdot 6^{\mathrm{a}}$ & 0.7 & $10 \cdot 5^{\mathrm{b}}$ & 1.8 \\
\hline $18: \ln -9$ & $13 \cdot 1^{a}$ & $1 \cdot 1$ & $25.8^{\mathrm{b}}$ & 1.4 & $16 \cdot 7^{\mathrm{a}}$ & 1.7 \\
\hline $18: 2 n-6$ & $51 \cdot 3^{\mathrm{a}}$ & $3 \cdot 0$ & $26 \cdot 4^{\mathrm{b}}$ & $3 \cdot 4$ & $39 \cdot 9^{\mathrm{c}}$ & $2 \cdot 2$ \\
\hline $20: 4 n-6$ & $6 \cdot 8^{\mathrm{a}}$ & 1.5 & $1.7^{\mathrm{b}}$ & 0.4 & $6 \cdot 3^{a}$ & $1 \cdot 4$ \\
\hline $\mathrm{mg} / \mathrm{g}$ & $1 \cdot 4^{a}$ & 0.6 & $6 \cdot 5^{\mathrm{b}}$ & $1 \cdot 4$ & $1 \cdot 3^{\mathrm{a}}$ & $0 \cdot 4$ \\
\hline
\end{tabular}

a, b,c Values in horizontal rows with different superscript letters were significantly different (one-way ANOVA and Duncan's Multiple Range Test): $P<0.01$.

2). In the phosphatidylcholine subclass the ratio of linoleic acid:arachidonic acid was higher in the $\mathrm{Zn}(-)$ group compared with the controls $(P<0.01)$; in the phosphatidylserine subclass the ratio was lower in the $\mathrm{Zn}(+)$ group compared with the controls $(P<0 \cdot 01)$.

In liver total phospholipid, linoleic acid was highest in the $\mathrm{Zn}(-)$ group, dihomo- $\gamma$ linoleic acid was highest in the $\mathrm{Zn}(+)$ group and arachidonic acid was not different between groups. The linoleic acid:arachidonic acid ratio was higher in the $\mathrm{Zn}(-)$ group than in the controls or $\mathrm{Zn}(+)$ group (Table 3$)$. The fatty acid composition of liver triacylglycerol is also shown in Table 3 . In the liver triacylgylcerol of the $\mathrm{Zn}(-)$ rats, proportional contents of palmitic acid and oleic acid were significantly lower whereas linoleic acid and arachidonic acid were significantly higher than those in the controls. In the liver triacylglycerol of the $\mathrm{Zn}(-)$ rats, proportional contents of palmitoleic acid, linoleic acid and arachidonic acid were higher than those in the controls but palmitic acid and oleic acid were lower. Total triacylglycerol was significantly lower in the $\mathrm{Zn}(-)$ and $\mathrm{Zn}(+)$ groups compared with controls.

\section{DISCUSSION}

The present study was designed to eliminate the variable of protein-energy intake while assessing the effects of dietary $\mathrm{Zn}$ deficiency on EFA composition in the rat. This was done by feeding approximately $3 \mathrm{mg} \mathrm{Zn} / \mathrm{kg}$ diet to rats which were at least $10 \mathrm{~d}$ beyond weaning age. It was reasoned that evidence suggesting a role of $\mathrm{Zn}$ in EFA metabolism would be strengthened if an effect of $\mathrm{Zn}$ supplementation opposite to that of $\mathrm{Zn}$ deficiency were observed. Since one-tenth the adequate $\mathrm{Zn}$ intake $(35-40 \mathrm{mg} / \mathrm{kg}$ ) was chosen for $\mathrm{Zn}$ depletion, ten times the adequate intake was used for $\mathrm{Zn}$ supplementation, an amount which does not adversely affect weight gain in rats (Table 1 and Cunnane, 1985).

The present observations indicate that a moderate degree of $\mathrm{Zn}$ depletion (3.4 mg Zn/ kg 
diet given from $10 \mathrm{~d}$ post-weaning for 10 weeks) does not significantly impair food intake in rats (Table 1) but does significantly alter EFA composition in plasma and liver phospholipids (Tables 2 and 3). The EFA changes in the $\mathrm{Zn}$-deficient rats resulted in an increase in the ratio of linoleic acid:arachidonic acid (higher linoleic acid or lower arachidonic acid depending on the phospholipid subclass; Tables 2 and 3) which is consistent with the majority of the previous experimental and clinical findings indicating an impairment of arachidonic acid synthesis during $\mathrm{Zn}$ deficiency.

The association between $\mathrm{Zn}$ and EFA does not depend only on the study of $\mathrm{Zn}$ deficiency. The present study included a group given ten times the amount of $\mathrm{Zn}$ given to the controls. The proportional content of arachidonic acid in plasma phosphatidylserine was significantly increased and the ratio, linoleic acid:arachidonic acid significantly decreased in the $\mathrm{Zn}(+)$ group compared with the controls (Table 2). These results are consistent with those previously reported showing higher arachidonic acid contents in liver phospholipids of $\mathrm{Zn}$-supplemented rats (Cunnane, 1985). They are also consistent with the low levels of arachidonic acid seen in human serum phospholipids of patients with both acquired and inherited $\mathrm{Zn}$ deficiency in whom $\mathrm{Zn}$ supplementation significantly raises the serum content of arachidonic acid (Koletzko et al. 1984; Krieger et al. 1986; Cunnane \& Krieger, 1988).

The explanation for the reported increase in the neutral lipid content (mol\%) of arachidonic acid (Huang et al. 1982; Cunnane et al. 1984; Cunnane, 1985; Fogerty et al. 1985 ) lies in the effect of the triacylglycerol pool size on its proportional composition of arachidonic acid. The proportional composition of arachidonic acid in plasma or liver triacylglycerol of various species has been shown to vary inversely with the triacylglycerol pool size (Cunnane et al. 1986). Hence when the liver triaclyglycerol pool size was decreased, e.g. the $75 \%$ decrease in liver triaclyglycerol seen in the $\mathrm{Zn}(-)$ and $\mathrm{Zn}(+)$ groups (Table 3), the proportional composition (mol\%) of arachidonic acid was significantly increased. The proportional increase in arachidonic acid in liver triaclyglycerol was not a function of increased synthesis of arachidonic acid but rather was a function of the triaclyglycerol pool size being reduced. In fact, the quantitative content of arachidonic acid in the liver triaclyglycerol was similar for the three groups in the present study: $\mathrm{Zn}(-) 95$, control $111, \mathrm{Zn}(+) 82 \mu \mathrm{g} / \mathrm{g}$. Therefore, in using differences in proportional fatty acid composition to approximate changes in EFA metabolism, it is essential to isolate the phospholipid (the total pool size of which rarely fluctuates more than $20 \%$ ) as has been recommended previously (Hill et al. 1982).

\section{REFERENCES}

American Institute of Nutrition (1977). Journal of Nutrition 107, 1340-1348.

Ayala, S. \& Brenner, R. R. (1983). Acta Physiologica Latinoamericana 33, 193-204.

Bettger, W. J., Reeves, P. G., Moscatelli, E. A., Reynolds, G. \& O'Dell, B. L. (1979). Journal of Nutrition 109, $480-488$.

Bieri, J. \& Prival, E. (1966). Journal of Nutrition 89, 55-61.

Clejan, S., Castro-Magana, M., Collipp, P. J., Jonas, E. \& Maddaiah, V. T. (1982). Lipids 17, 129-135.

Cunnane, S. C. (1982). Progress in Lipid Research 21, 73-90.

Cunnane, S. C. (1985). In Trace Elements in Man and Animals, vol. 5, pp. 70-75 [C. F. Mills, I. Bremner and J. K. Chesters, editors]. Slough: Commonwealth Agricultural Bureaux.

Cunnane, S. C., Huang, Y.-S. \& Manku, M. S. (1986). Biochimica Biophysica Acta 876, 183-186.

Cunnane, S. C. \& Krieger, I. (1988). Journal of the American College of Nutrition (In the Press).

Cunnane, S. C., Manku, M. S. \& Horrobin, D. F. (1984). Proceedings of the Society for Experimental Biology and Medicine 177, 141-146.

Fields, H. P. \& Kelleher, J. (1983). Proceedings of the Nutrition Society 43, 54A.

Fogerty, A. C., Ford, G. L., Dreosti, I. E. \& Tinsley, I. J. (1985). Nutrition Reports International 32, $1009-1020$.

Hill, E. G., Johnson, S. B., Lawson, L. D., Mafouz, M. M. \& Holman, R. T. (1982). Proceedings of the National Academy of Sciences, USA 79, 953-957. 
Huang, Y. S., Cunnane, S. C., Horrobin, D. F. \& Davignon, J. (1982). Atherosclerosis 42, 193-207.

Koletzko, B., Bretschneider, A. \& Bremer, H. J. (1984). European Journal of Pediatrics 143, 310-313.

Kramer, T. R., Briske-Anderson, M., Johnson, S. B. \& Holman, R. T. (1984). Journal of Nutrition 114, 1224-1230.

Krieger, I., Alpern, B. E. \& Cunnane, S. C. (1986). American Journal of Clinical Nutrition 43, $955-958$.

Odutunga, A. A. (1982). Clinical and Experimental Pharmacology and Physiology 9, 213-221.

Stewart, J. C. M. (1980). Analytical Biochemistry 104, 10-14.

Tsai, S. L., Craig-Schmidt, M. C., Weete, J. D. \& Keith, R. E. (1983). Federation Proceedings 42, 823. 